Print ISSN: 2502-1397 / Online ISSN 2540-8100

https://doi.org/10.32505/j-ebis.v6i1.2684

\title{
GOOD CORPORATE GOVERNANCE, PROFITABILITAS, KEBIJAKAN DEVIDEN DAN NILAI PERUSAHAAN PADA KONSTITUEN JAKARTA ISLAMIC INDEX 70
}

\author{
Evan Hamzah Muchtar*, Wahyu Hidayat**, Titis Astreanih*** \\ *STAI Asy-Syukriyyah Tangerang, evan.hamzah.m@gmail.com \\ ***STAI Asy-Syukriyyah Tangerang, wahyu.hidayat@asy-syukriyyah.ac.id \\ **STAI Asy-Syukriyyah Tangerang, titisastreanih98@gmail.com
}

\begin{abstract}
This study aims to determine the impact of good corporate governance, profitability, dividend policy on firm value in the constituents of the Jakarta Islamic Index 70. A total of 98 companies out of a total population of 140 companies listed on the Jakarta Islamic Index 70 in 2017-2018 have been selected as research samples with this technique purposive sampling. The data analysis method used is panel data regression analysis using E-views 8 Student Version software. The results showed that simultaneously good corporate governance, profitability and dividend policy had a significant effect on firm value. Partially, the research results show that good corporate governance and dividend policy have no significant effect on firm value. While profitability based on the results of the study showed a significant effect on firm value. To increase the value of the company, it is necessary to implement good corporate governance optimally not only to reach the standards set by regulations but also to make good corporate governance a work culture within the company and also review the dividend policy issued by the company regarding how much the ratio of dividend payments to shareholders is.
\end{abstract}

Keywords: Corporate Governance; Profitability; Dividend Policy; Company Value; Jakarta Islamic Index 70

\begin{abstract}
Abstrak
Penelitian ini bertujuan untuk mengetahui pengaruh good corporate governance, profitabilitas, kebijakan deviden terhadap nilai perusahaan pada konstituen Jakarta Islamic Index 70. Sebanyak 98 perusahaan dari total populasi 140 perusahaan yang terdaftar di Jakarta Islamic Index 70 tahun 2017-2018 telah dipilih sebagai sampel penelitian dengan teknik purposive sampling. Metode analisis data yang digunakan adalah analisis regresi data panel dengan menggunakan software E-views 8 Student Version. Hasil penelitian menunjukkan bahwa secara simultan good corporate governance, profitabilitas dan kebijakan deviden berpengaruh signifikan terhadap nilai perusahaan. Secara parsial, hasil penilitian menunjukkan good corporate governance dan kebijakan deviden tidak berpengaruh signifikan terhadap nilai perusahaan. Sedangkan profitabilitas berdasarkan hasil penelitian menunjukkan
\end{abstract}


berpengaruh signifikan terhadap nilai perusahaan. Dalam upaya meningkatkan nilai perusahaan diperlukan adanya penerapan good corporate governance secara maksimal bukan hanya untuk memenuhi standar yang ditetapkan regulasi melainkan juga menjadikan good corporate governance sebagai budaya kerja dalam perusahaan serta meninjau kembali kebijakan dividen yang dikeluarkan perusahaan mengenai seberapa besar rasio pembayaran dividen kepada para pemegang saham.

Kata Kunci: Corporate Governance; Profitabilitas; Kebijakan Deviden; Nilai Perusahaan; Jakarta Islamic Index 70

\section{PENDAHULUAN}

Peningkatan nilai perusahaan akan terlihat dari seberapa besar harga saham dipasaran, karena penilaian yang diberikan oleh calon investor mengenai perusahaan dapat dilihat dari naik turunnya harga saham perusahaan yang telah di transaksikan didalam Bursa Efek Indonesia pada perusahaan yang sudah go public (Lestari, 2019: 1). Pertimbangan investor ketika ingin menanamkan modalnya pada perusahaan bukan hanya melihat dari seberapa besar harga saham perusahaan, namun juga dilihat dari seberapa patuh perusahaan dalam menerapkan praktik tata kelola perusahaan (corporate governance). Corporate governance digunakan untuk mengatur hubungan antara pihak eksternal dan pihak internal perusahaan. Tata kelola perusahaan yang baik (Good Corporate Governance) memiliki peran penting untuk mendukung berjalannya kegiatan perusahaan (Kurnianto, Sadarwati \& Burhanudin, 2019: 13)

Good corporate governance sudah diterapkan di Indonesia pada pertengahan tahun 1997 diakibatkan adanya krisis ekonomi. Isu governance secara global menguat setelah runtuhnya beberapa bisnis raksasa dunia seperti Enron dan World Com di Amerika Serikat, serta tragedi jatuhnya HIH Insurance dan One-Tell di Australia. Isu governance semakin berkembang setelah World Bank dan Asian Development Bank (ADB) mengungkap bahwa krisis keuangan yang terjadi di berbagai negara Asia di sebabkan oleh buruknya pelaksanaan corporate governance, sehingga mengakibatkan Indonesia sebagai negara yang paling menderita dan sulit bangkit dari krisis tersebut (Lukviarman, 2016: 25). Ketua Dewan Komisioner Otoritas Jasa Keuangan (OJK) Wimboh Santoso (2017) mengatakan penerapan good corporate governance di Indonesia tertinggal di bandingkan dengan negara-negara di kawasan ASEAN. Hanya dua emiten dari 
Evan Hamzah Muchtar, dkk: Good corporate governance, profitabilitas, kebijakan deviden

Indonesia yang masuk dalam daftar 50 emiten terbaik dalam praktik Good Corporate Governance di ASEAN dalam ajang penganugerahan ASEAN Corporate Governance Awards 2015 yang diselenggarakan oleh ASEAN Capital Markets Forum (ACMF) di Manila, Filipina. Kedua emiten tersebut yaitu PT Bank Danamon Tbk dan PT Bank CIMB Niaga Tbk. Pencapaian Indonesia ini tertinggal jauh dari Thailand yang mampu menempatkan 23 emiten, Filipina 11 emiten, Singapura delapan emiten dan Malaysia enam emiten (primadhyta, 2017).

Lemahnya penerapan good corporate governance di Indonesia pada perusahaan yang sudah go public dikarenakan kurangnya kesadaran akan suatu nilai dan praktek dasar dalam menjalankan bisnis, meskipun saat ini perusahaan berlomba-lomba untuk melaksanakan good corporate governance, namun baru hanya sebatas pada pemenuhan runtutan bisnis. Pada kenyataannya sistem governance belum dijalankan secara maksimal (Nursito, 2019: 833).

Perusahaan melaksanakan praktik good corporate governance masih sebatas pada pemenuhan terhadap berbagai peraturan yang berlaku. Seharusnya dengan adanya penerapan good corporate governance mampu meningkatkan nilai perusahaan (Nursito, 2019). Dalam sebuah artikel Wareza (2019) menyampaikan kasus mengenai corporate governance kembali diperbincangkan saat terjadinya penyelundupan motor mewah Harley Davidson dan sepeda Brompton di pesawat Airbus A330-900 Neo milik PT Garuda Indonesia Tbk (GIAA), kasus tersebut melibatkan Direktur Utama dan empat Direksi lainnya. Aksi tidak terpuji yang melanggar prinsip good corporate governance (GCG) mengakibatkan pelaku pasar bursa bereaksi negatif, sehingga mengakibatkan harga saham PT Garuda Indonesia anjlok.

Selain good corporate governance, ada faktor lain dalam meningkatkan nilai perusahaan adalah tingkat profitabilitas dan kebijakan dividen (Puspitaningtyas, 2017: 174). Tingkat profitabilitas di jadikan oleh investor sebagai salah satu informasi yang penting sebelum melakukan investasi. Kondisi yang profitabel juga menjadi salah satu tujuan perusahaan. Kemampuan perusahaan diukur dengan seberapa besar tingkat profitabilitas atau keuntungan yang dihasilkan dalam periode tertentu. Lebih lanjut Puspitaningtyas (2017: 174) menyatakan Profitabilitas dikatakan penting karena profitabilitas sebagai indikator dalam 
mengukur kinerja keuangan perusahaan, sehingga dapat dijadikan acuan untuk menilai perusahaan. Perusahaan dengan tingkat profitabilitas tinggi mencerminkan nilai perusahaan yang tinggi pula, dan sebaliknya.

Menurut Widyanti (2014: 1.049) semakin tinggi profitabilitas suatu perusahaan menunjukkan bahwa perusahaan tersebut memiliki prospek yang baik, sehingga memicu investor dalam ikut meningkatkan permintaan saham. Permintaan saham yang meningkat akan berdampak pada naiknya nilai perusahaan. Purnama (2016: 18) menyatakan Profitabilitas yang tinggi akan memberikan sinyal positif bagi investor bahwa perusahaan berada dalam kondisi yang menguntungkan. Hal ini menjadi daya tarik investor untuk memiliki saham perusahaan tersebut, sehingga permintaan saham yang tinggi akan membuat para investor menghargai nilai saham lebih besar dari pada nilai yang tercatat pada neraca perusahaan, sehingga nilai PBV perusahaan tinggi dan nilai perusahaan pun tinggi.

Pasar Modal Syariah di Indonesia semakin kompetitif sejak diluncurkannya indeks saham syariah pertama kali pada 3 Juli 2000 yaitu Jakarta Islamic Index (JII). Indeks ini hanya terdiri dari 30 saham paling likuid di Pasar Modal Syariah yang konstisten selama dua periode seleksi, yaitu bulan Mei dan November setiap tahunnya. Kemudian diluncurkan Indeks Saham Syariah Indonesia (ISSI) pada tanggal 12 Mei 2011. Bursa Efek Indonesia (BEI) mengeluarkan indeks saham syariah baru, yaitu Jakarta Islamic Index 70 (JII 70), pada 17 Mei 2018. Indeks saham ini sama seperti indeks saham syariah sebelumnya yaitu Jakarta Islamic Index (JII) 30, hanya saja indeks ini terdiri dari 70 perusahaan dengan saham paling likuid setiap periodenya (Otoritas Jasa Keuangan, 2019: 167).

Jakarta Islamic Index 70 merupakan salah satu indeks saham syariah yang ada di Indonesia yang menghitung indeks harga rata-rata saham untuk jenis saham yang memenuhi kriteria atau prinsip Islam. JII 70 diluncurkan untuk merespon kebutuhuan masyarakat terhadap instrumen syariah yang semakin berkembang sampai saat ini. Tujuan peluncuran JII 70 adalah untuk meningkatkan kepercayaan investor dan mendukung para pemodal dalam menjalankan syariat Islam untuk berinvestasi di bursa efek (Senjani \& Wibantoro, 2018: 282).

Dengan adanya Jakarta Islamic Index 70 diharapkan dapat menjadi tolak ukur investor dalam memilih saham yang berbasis syariah serta untuk 
mengembangkan pasar modal syariah. JII 70 menjadi alternatif bagi para investor Indonesia yang umumnya merupakan masyarakat muslim yang ingin menanamkan dananya secara syariah tanpa takut tercampur dengan dana ribawi. Selain itu, keuntungan yang didapat oleh investor dari hasil investasi berdasarkan prinsip bagi Hasil (Senjani \& Wibantoro, 2018: 282). Hal ini karena perusahaan yang masuk dalam JII 70 terhindar dari sektor kegiatan usaha barang dan jasa yang haram, seperti perusahaan rokok dan miras yang tidak termasuk dalam daftar saham syariah.

Perkembangan indeks saham syariah untuk JII dan ISSI dari tahun 2015 hingga tahun 2017 selalu mengalami peningkatan. Pada tahun 2016 kapitalisasi saham JII sebesar Rp2.035 miliar meningkat dibandingkan dengan tahun 2015 yang hanya sebesar Rp1.737 miliar. Begitu juga dengan saham ISSI pada tahun 2016 kapitalisasi saham meningkat sebesar Rp3.170 miliar dari tahun sebelumnya yang hanya Rp2.600 miliar. Kapitalisasi saham JII 70 yang baru diluncurkan pada 2018 juga mengalami peningkatan dari tahun 2018 hingga 2019, kapitalisasi saham tahun 2018 sebesar Rp2.715 miliar meningkat menjadi Rp2.800 miliar. Selain itu pada penutupan akhir tahun 2018, JII70 ditutup pada level 227,5 meningkat 1,29\% sejak diterbitkan. Berikut perkembangan indeks JII70 sejak diluncurkan pada bulan Mei 2018 hingga akhir tahun 2018 (Otoritas Jasa Keuangan, 2019: 168).

Gambar 1 Perkembangan Indeks JII70 Selama Tahun 2018

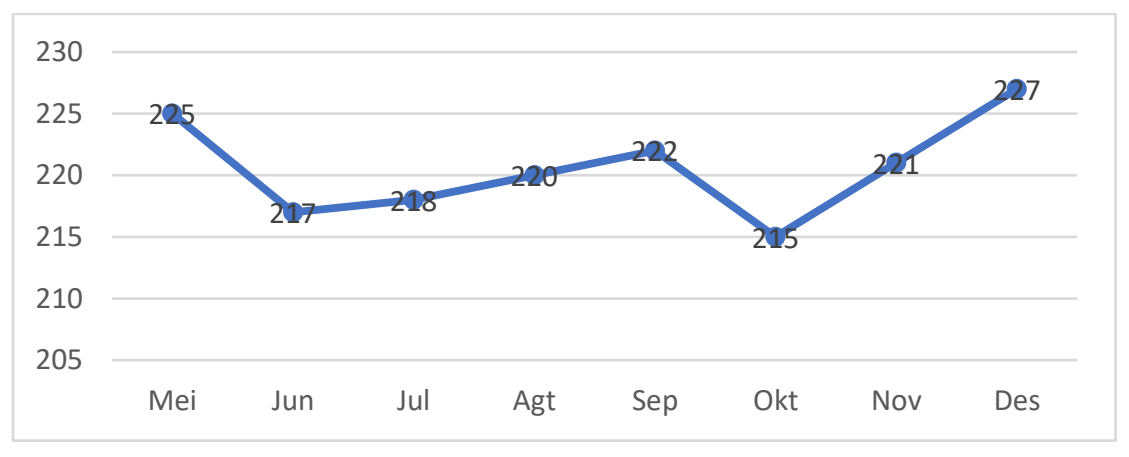

Terdapat beberapa penelitian terdahulu yang terkait penelitian ini, diantaranya dilakukan oleh Muchtar, Nuruddin \& Siregar (2019: 195). Hasil penelitian mengungkapkan bahwa tata kelola perusahaan memiliki pengaruh negatif dan tidak signifikan terhadap nilai perusahaan. Profitabilitas yang diukur dengan Return on Asset (ROA) dan Return on Equity (ROE) memiliki pengaruh positif dan signifikan terhadap Nilai Perusahaan. Selain itu Tata Kelola Perusahaan 
memiliki pengaruh positif dan signifikan terhadap Nilai Perusahaan ketika dimediasi oleh Profitabilitas (Muchtar, Nuruddin \& Siregar 2019: 196). Selanjutnya penelitian yang dilakukan oleh Ayuningrum dan Saputra (2017) menyatakan jika good corporate governance berpengaruh positif dan signifikan terhadap nilai perusahaan.

Mustafa dan Junaid (2018: 9) dalam penelitiannya menyatakan kebijakan deviden tidak berpengaruh terhadap nilai perusahaan. Selain itu kebijakan deviden juga tidak mampu memoderasi hubungan antara keputusan investasi dengan nilai perusahaan. Penelitian yang dilakukan oleh Hidayah dan Widyawati (2016: 1) menunjukkan profitabilitas berpengaruh positif terhadap nilai perusahaan. Namun hasil berbeda berdasarkan penelitian diperoleh hasil jika kebijakan deviden tidak berpengaruh terhadap nilai perusahaan.

Perbedaan penelitian ini dengan terdahulu adalah objek yang diambil oleh penulis yaitu menggunakan populasi seluruh perusahaan terbuka yang terdaftar di Jakarta Islamic Index 70 (JII70) pada tahun 2018 dan 2019. Indeks JII 70 yang diluncurkan pada Mei tahun 2018 ini mengalami peningkatan hingga akhir tahun 2018. Selain itu juga kapitalisasi saham meningkat pada tahun 2019 jika dibandingkan dengan tahun 2018. Oleh karena itu penulis tertarik melakukan penelitian untuk mengetahui seberapa besar pengaruh dari penerapan good corporate governance, profitabilitas dan kebijakan dividen terhadap peningkatan nilai perusahaan pada emiten JII 70. Adapun manfaat penelitian ini diharapkan dapat memberikan informasi untuk mempertimbangkan keputusan investasi yang berkaitan dengan penerapan good corporate governance, profitabilitas dan kebijakan dividen. Sehingga calon investor dapat memilih perusahaan terbuka yang terdaftar di Jakarta Islamic Index 70 dengan mempertimbangkan perusahaan mana yang memiliki prospek yang menguntungkan dimasa mendatang serta dapat meningkatkan kesejahteraan para investor.

\section{LANDASAN TEORITIS}

\section{Pasar Modal Syariah}

Keberadaan Undang-Undang Republik Indonesia Nomor 8 Tahun 1995 tentang Pasar Modal (UUPM) menjadi pemicu kehadiran beragam produk investasi 
di pasar modal Indonesia. Termasuk juga efek syariah yang menjadi tonggak sejarah perkembangan pasar modal syariah di Indonesia. Menurut Otoritas Jasa Keuangan (2019: 131) pasar modal syariah dapat diartikan sebagai kegiatan dalam pasar modal sebagaimana diatur dalam UUPM yang tidak bertentangan dengan prinsip syariah. Penerapan prinsip syariah di pasar modal sendiri diatur dalam Peraturan Otoritas Jasa Keuangan Nomor 15/POJK.04/2015 tentang Penerapan Prinsip Syariah di Pasar Modal.

Pasar modal syariah memiliki 2 (dua) peran besar dalam perekonomian suatu negara. Pertama, sebagai sumber pendanaan bagi perusahaan untuk pengembangan usahanya melalui penerbitan efek syariah. Kedua, sebagai sarana investasi (efek syariah) bagi investor (Otoritas Jasa Keuangan, 2019: 134). Menurut Abdalloh (2018) perkembangan pasar modal syariah di Indonesia dibagi menjadi dua bagian. Fase pertama adalah kelahiran pasar modal syariah Indonesia pada tahun 1997 dengan diterbitkannya reksa dana syariah oleh Danareksa Investment Management (DIM). Dilanjutkan fase kedua adalah kebangkitan pasar modal syariah di Indonesia dengan diluncurkannya Indeks Saham Syariah Indonesia (ISSI) pada tahun 2011.

\section{Jakarta Islamic Index 70}

Jakarta Islamic Index 70 (JII70) adalah indeks saham syariah yang diluncurkan Bursa Efek Indonesia (BEI) pada tanggal 17 Mei 2018. Konstituen JII70 hanya terdiri dari 70 saham syariah paling likuid yang tercatat di BEI. Review saham syariah yang menjadi konstituen JII70 dilakukan pada bulan Mei dan November setiap tahunnya mengikuti jadwal review Daftar Efek Syariah (DES) oleh Otoritas Jasa Keuangan (Otoritas Jasa Keuangan, 2019: 167).

BEI menentukan dan melakukan seleksi saham syariah yang menjadi konstituen JII70 (www.idx.co.id). Adapun kriteria likuditas yang digunakan dalam menyeleksi 70 saham syariah yang menjadi konstituen JII70 adalah sebagai berikut:

1. Saham syariah yang masuk dalam konstituen Indeks Saham Syariah Indonesia (ISSI) telah tercatat selama 6 bulan terakhir

2. Dipilih 150 saham berdasarkan urutan rata-rata kapitalisasi pasar tertinggi selama 1 tahun terakhir. 
3. Dari 150 saham tersebut, kemudian dipilih 70 saham berdasarkan rata-rata nilai transaksi harian di pasar regular tertinggi.

4. 70 saham yang tersisa merupakan saham terpilih.

\section{Nilai Perusahaan}

Nilai perusahaan merupakan kondisi tertentu yang telah dicapai oleh suatu perusahaan sebagai gambaran dari kepercayaan masyarakat terhadap perusahaan setelah melalui suatu proses kegiatan selama beberapa tahun (Brigham \& Gapenski, 2011: 103). Gitman (2006: 352) menjelaskan nilai perusahaan adalah nilai aktual per lembar saham yang akan diterima apabila aset perusahaan dijual sesuai harga saham.

Nilai perusahaan merupakan persepsi investor terhadap tingkat keberhasilan perusahaan yang terkait erat dengan harga sahamnya. Harga saham yang tinggi membuat nilai perusahaan juga tinggi, dan meningkatkan kepercayaan pasar tidak hanya terhadap kinerja perusahaan saat ini namun juga pada prospek perusahaan di masa mendatang (Ganar, 2018: 34). Perusahaan dengan kinerja yang baik akan membuat investor bersedia membayar lebih untuk membeli saham perusahaan. Jadi dapat dikatakan bahwa nilai perusahaan dapat diartikan sebagai harga yang bersedia dibayar oleh investor untuk memiliki suatu perusahaan (Putra \& Juniariani, 2017: 144).

Weston dan Copeland (2001: 18) menyatakan tujuan utama perusahaan adalah memaksimumkan nilai perusahaan. Memaksimalkan nilai perusahaan mempunyai makna yang lebih luas, tidak hanya sekedar memaksimalkan laba perusahaan. Lebih lanjut Muchtar (2021: 96) menyatakan memaksimalkan nilai perusahaan sangat penting artinya bagi suatu perusahaan, karena dengan memaksimalkan nilai perusahaan berarti juga memaksimalkan tujuan utama perusahaan. Meningkatnya nilai perusahaan adalah sebuah prestasi yang sesuai dengan keinginan para pemiliknya, karena dengan meningkatnya nilai perusahaan, maka kesejahteraan para pemilik juga akan meningkat.

\section{Good Corporate Governance}

Organization for Economics Co-operation and Development (OECD, 1999) memberikan definisi 'corporate govenance is the process by which companies are directed and controlled'. Definisi ini memberikan penekanan pada unsur 
Evan Hamzah Muchtar, dkk: Good corporate governance, profitabilitas, kebijakan deviden

pengarahan (directed) dan pengendalian (controlled) di dalam rangkaian proses tata kelola perusahaan.

Pengertian lain menurut Monks dan Minow dalam Lukviarman (2016: 20) menyatakan corporate governance sebagai upaya menjaga hubungan antara pemilik atau pemegang saham, manajemen perusahaan, dan dewan komisaris (Board of Directors). Hubungan antara ketiga unsur tersebut dalam corporate governance akan menentukan arah dan kinerja perusahaan sesuai dengan mekanisme yang ditetapkan.

Effendy (2009: 2) memberikan definisi tata kelola perusahaan sebagai seperangkat sistem yang mengatur dan mengendalikan perusahaan untuk menciptakan nilai tambah (value added) bagi para pemangku kepentingan. Lebih lanjut Sutedi (2012: 1) mendefinisikan corporate governance sebagai suatu proses dan struktur yang digunakan oleh organ perusahaan (pemegang saham/pemilik modal, komisaris/dewan pengawas dan direksi) untuk meningkatkan keberhasilan usaha dan akuntabilitas perusahaan guna mewujudkan nilai pemegang saham dalam jangka penjang dengan tetap memperhatikan kepentingan stakeholder lainnya, berlandaskan peraturan perundang-undangan dan nilai-nilai etika.

Prinsip-Prinsip good corporate governance meliputi keterbukaan (transparency), akuntabilitas (accountability), pertanggungjawaban (responsibility), kemandirian (independence) dan kesetaraan (fairness) (Muchtar, 2021: 38). Berdasarkan Pedoman Umum Good Corporate Governance Indonesia yang diterbitkan oleh Komite Nasional Kebijakan Governance (2016: 5-7) prinsipprinsip tersebut diperlukan untuk mencapai kesinambungan usaha (sustainability) perusahaan dengan memperhatikan pemangku kepentingan.

\section{Profitabilitas}

Munawir (2007: 33) menyatakan profitabilitas adalah kemampuan perusahaan untuk menghasilkan laba selama periode tertentu, yang diukur dengan kesuksesan perusahaan dan kemampuan menggunakan aktivanya secara produktif dengan membandingkan antara laba yang diperoleh dalam suatu periode dengan jumlah aktiva atau jumlah modal perusahaan tersebut.

Profitabilitas merupakan rasio yang digunakan untuk menilai kemampuan perusahaan dalam mencari keuntungan. Rasio ini juga memberikan ukuran tingkat 
efektivitas manajemen suatu perusahaan. Hal ini ditujukan oleh laba yang dihasilkan dari penjualan dan pendapatan investasi (Agustina \& Rahmiyati, 2019: 105).

Rasio profitabilitas bermanfaat untuk menunjukan keberhasilan perusahaan di dalam menghasilkan keuntungan. Investor yang potensial akan menganalisis dengan cermat kelancaran sebuah perusahaan dari kemampuannya untuk mendapatkan keuntungan (profitabilitas), karena mereka mengharapkan dividend dan harga pasar dari sahamnya. Rasio ini dimaksudkan untuk mengukur efisiensi penggunaan aktiva tetap (Fahmi, 2014: 116).

\section{Kebijakan Deviden}

Kebijakan deviden (Dividend policy) merupakan keputusan yang diambil perusahaan terkait laba yang diperoleh perusahaan pada akhir tahun apakah akan dibagikan kepada pemegang saham dalam bentuk dividen atau akan ditahan untuk menambah modal yang akan dipergunakan sebagai pembiayaan investasi dimasa yang akan datang (Dominique, 2019: 20). Brigham dan Houston (2001: 66-68) menyatakan kebijakan dividen pada dasarnya adalah penentuan besarnya porsi keuntungan yang akan dibagikan kepada pemegang saham. Lebih lanjut Brigham dan Houston memaparkan terdapat 3 (tiga) teori mengenai kebijakan deviden yaitu Dividend Irrelevance Theory, Bird in The Hand Theory dan Tax Preference Theory.

Setiawan dan Riduwan (2015: 9) menyatakan dividen diberikan setelah mendapat persetujuan dari para pemegang saham dalam Rapat Umum Pemegang Saham (RUPS). Pemegang saham atau investor yang berhak menerima dividen adalah investor yang memegang saham sampai batas waktu yang ditentukan oleh perusahaan pada saat pengumuman dividen. Adapun indikator untuk mengukur kebijakan deviden menurut Fahmi (2014: 170) adalah dividend payout ratio (DPR) dan dividend yield. 
Evan Hamzah Muchtar, dkk: Good corporate governance, profitabilitas, kebijakan deviden

\section{Kerangka Konseptual}

Penelitian ini bertujuan untuk mengetahui pengaruh penerapan good corporate governance (X1) yang mengacu kepada Pedoman Penerapan Tata Kelola Perusahaan Terbuka, profitabilitas (X2) yang diukur dengan return on asset (ROA) dan kebijakan dividen (X3) yang diukur dengan dividend payout ratio (DPR) terhadap nilai perusahaan (Y) yang diukur dengan Tobin's $Q$. Berikut disampaikan model kerangka konseptual dalam penelitian ini:

\section{Gambar 2 Kerangka Konseptual}

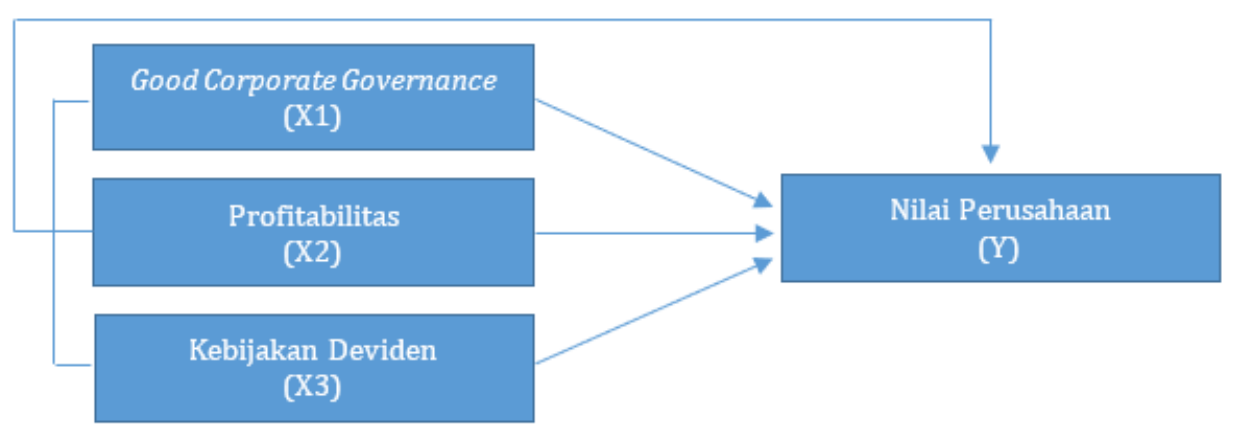

\section{METODE}

Metode yang diambil dalam penelitian ini yaitu kuantitatif bertujuan untuk menguji hipotesis yang telah ditetapkan (Siyoto dan Sodik, 2015: 18). Data yang digunakan dalam penelitian ini yaitu data sekuder berupa laporan keuangan (financial statement) tahunan yang sudah diaudit dan laporan tahunan (annual report) pada perusahaan yang terdaftar di Jakarta Islamic Index 70 (JII70).

Populasi dalam penelitian ini sebanyak 140 perusahaan terbuka yang terdaftar di Jakarta Islamic Index 70 dalam jangka waktu kegiatan operasional di Indonesia dari tahun 2018-2019. Sampel penelitian ditentukan dengan teknik purposive sampling yaitu teknik penentuan dan pengambilan sampel yang ditentukan oleh peneliti dengan kriteria tertentu (Sugiyono, 2017: 80). Adapun kriteria dalam penelitian ini disajikan pada tabel berikut: 
Tabel 1. Kriteria Penentuan Sampel

\begin{tabular}{clc}
\hline No. & \multicolumn{1}{c}{ Kriteria } & Total \\
\hline 1 & Emiten yang terdaftar di JII70 pada tahun 2018 dan 2019 & 140 \\
2 & $\begin{array}{l}\text { Emiten menyampaikan Penerapan Pedoman Tata Kelola } \\
\text { Perusahaan Terbuka pada Laporan Tahunan 2018 dan 2019 }\end{array}$ & 132 \\
& $\begin{array}{l}\text { Emiten menghasilkan laba pada tahun 2018-2019 } \\
3\end{array}$ & 128 \\
4 & Emiten melakukan pembayaran Devidend Payout Ratio pada & 98 \\
& tahun 2018-2019 & \\
\hline
\end{tabular}

Teknik analisis yang digunakan dalam penelitian ini adalah regresi data panel. Data panel adalah gabungan antara data runtut waktu (time series) dan data silang (cross section) (Basuki dan Prawoto, 2016). Penelitian ini menggunakan regresi data panel karena data pada penelititan ini adalah gabungan antara data runtut waktu dan data silang serta untuk mengukur pengaruh variabel independen terhadap variabel dependen. Pengolahan dan analisis data dilakukan dengan menggunakan software Eviews 8.

Terdapat tiga pendekatan yang digunakan dalam menduga model dari data panel yaitu Commond Effect Model (The Pooled Ordinary Least Square Method atau PLS), Fixed Effect Model (FEM) dan Random Effect Model (REM). Untuk dapat menentukan model terbaik dalam mengestimasi regresi data panel dari ketiga pendekatan tersebut, maka digunakanlah dua teknik estimasi model, yaitu pertama Uji Chow (chow test) yang digunakan untuk memilih antara common effect atau fixed effect model. Kemudian yang kedua Uji Hausmen (hausman test) merupakan uji yang digunakan untuk memilih model antara model fixed effect atau model random effect. Dari kedua uji tersebut dipilih model mana yang terbaik dalam menentukan regresi data panel (Lestari, 2019: 74).

Hipotesis pengujian Chow Test yaitu H0 : Common Effect Model Ha : Fixed Effect Model. Jika P-Value < $\alpha$ (taraf signifikansi/alpha), maka hipotesis H0 ditolak, sehingga model yang terpilih adalah Fixed Effect Model. Sebaliknya, Jika P-Value $>\alpha$, maka hipotesis H0 diterima. Sehingga model yang terpilih adalah Common Effect Model. Nilai a yang digunakan adalah 
sebesar 0,05 atau 5\%. Sedangkan Hipotesis pengujian Hausman Test yaitu H0 : Random Effect Model Ha : Fixed Effect Model Jika P-Value < a (taraf signifikansi/alpha), maka hipotesis H0 ditolak, sehingga model yang terpilih adalah Fixed Effect Model. Sebaliknya, Jika P-Value> $\alpha$, maka hipotesis H0 diterima. Sehingga model yang terpilih adalah Random Effect Model. Nilai $\alpha$ yang digunakan adalah sebesar 0,05 atau $5 \%$.

Pada penelitian ini, peneliti ingin menguji pengaruh penerapan good corporate governance, profitabilitas dan kebijakan dividen terhadap nilai perusahaan. Adapun persamaan regresi data panel sebagai berikut :

$$
\text { Yit }=\beta i t+\sum_{k=2}^{K}+\beta \text { kit Xkit }+£ i t
$$

Dimana :

$\mathrm{i} \quad=1,2, \ldots \ldots . \mathrm{N}$

$\mathrm{N} \quad=$ Banyak unit cross section

$\mathrm{T}=$ Banyak data time series

$\mathrm{Y}_{\mathrm{it}} \quad=$ Nilai variabel terikat cross section ke- $i$ time series ke- $t$

$\mathrm{X}_{\mathrm{it}} \quad=$ Nilai variabel terikat ke- $k$ untuk cross section ke- $i$ tahun ke- $t$

$\beta_{\text {it }} \quad=$ Parameter yang ditaksir

$\mathfrak{f}_{\text {it }} \quad=$ Unsur gangguan populasi

$\mathrm{K}=$ Banyak parameter yang ditaksir

Dalam pengujian hipotesis uji yang digunakan adalah uji T (uji parsial), uji F (uji serempak) dan koefisien determinasi $\left(\mathrm{R}^{2}\right)$. Uji $\mathrm{T}$ dilakukan dengan cara membandingkan t-hitung dengan t-tabel atau bisa juga dilakukan dengan cara melihat kolom signifikansi pada masing-masing t-hitung. Ketentuan dalam pengujian ini adalah jika t-hitung $<\mathrm{t}$-tabel maka tidak ada pengaruh yang signifikan antara variabel bebas terhadap variabel terikat. Namun jika sebaliknya t-hitung $>\mathrm{t}$ tabel, maka ada pengaruh yang signifikan antara variabel bebas terhadap variabel terikat. Dengan demikian, $\mathrm{H}_{0}$ ditolak dan menerima $\mathrm{H}_{\mathrm{a}}$, pada tingkat signifikansi $\alpha=5 \%$ atau 0,05 . Adapun hipotesis dalam penelitian ini adalah sebagai berikut: 
1. Pengaruh Good corporate governance terhadap nilai perusahaan

$\mathrm{H}_{\mathrm{o}} 1$ : Good corporate governance tidak berpengaruh terhadap nilai perusahaan

$\mathrm{H}_{\mathrm{a}} 1$ : Good corporate governance berpengaruh terhadap nilai perusahaan

2. Pengaruh Profitabilitas terhadap nilai perusahaan

$\mathrm{H}_{\mathrm{o}} 2$ : Profitabilitas tidak berpengaruh terhadap nilai perusahaan

$\mathrm{H}_{\mathrm{a}} 2$ : Profitabilitas berpengaruh terhadap nilai perusahaan

3. Pengaruh kebijakan deviden terhadap nilai perusahaan

$\mathrm{H}_{\mathrm{o}} 3$ : Kebijakan deviden tidak berpengaruh terhadap nilai perusahaan

$\mathrm{H}_{\mathrm{a}} 3$ : Kebijakan deviden berpengaruh terhadap nilai perusahaan

4. Pengaruh Good corporate governance, profitabilitas dan kebijakan deviden secara simultan terhadap nilai perusahaan

$\mathrm{H}_{\mathrm{o}} 4$ : Good corporate govenance, profitabilitas dan kebijakan deviden secara simultan tidak berpengaruh terhadap nilai perusahaan

$\mathrm{H}_{\mathrm{a}} 4$ : Good corporate govenance, profitabilitas dan kebijakan deviden secara simultan tidak berpengaruh terhadap nilai perusahaan

Penggunaan digunakan uji statistik $\mathrm{F}$ dengan kriteria pengambilan keputusan apabila nilai signifikansi value $F$ test $<0,05$ maka berarti model regresi dapat digunakan untuk memprediksi variabel dependen. Atau dapat dikatakan bahwa variabel-variabel independen secara bersama-sama berpengaruh terhadap variabel dependen (Ghozali \& Dwi, 2016). Sedangkan uji koeefisien determinasi $\left(\mathrm{R}^{2}\right)$ mengetahui seberapa besar prosentase pengaruh variabel bebas $(\mathrm{X})$ terhadap variabel terikat (Y) yang dimasukan dalam model. Menurut Kuncoro (2013: 246) Nilai koefisien determinasi / R2 berada pada rentang angka nol (0) dan satu (1). Jika nilai koefisien determinasi yang mendekati angka nol (0) berarti kemampuan model dalam menerangkan variabel terikat sangat terbatas. Sebaliknya apabila nilai koefisien determinasi variabel mendekati satu (1) berarti kemampuan variabel bebas dalam menimbulkan keberadaan variabel terikat semakin kuat.

Untuk mengetahui pengaruh Penerapan good corporate governance, profitabilitias, dan kebijakan deviden secara simultan terhadap Nilai perusahaan menggunakan uji F. Uji ini digunakan untuk mengetahui apakah variabel independen secara bersama-sama berpengaruh terhadap variabel dependen atau untuk mengetahui apakah model regresi dapat digunakan untuk memprediksi 
variabel dependen atau tidak. Apabila nilai $\mathrm{F}$ hitung $>\mathrm{F}$ tabel maka $\mathrm{H}_{0}$ ditolak dan dapat disimpulkan bahwa variabel independen secara simultan mempengaruhi variabel dependennya. Apabila nilai $\mathrm{F}$ hitung $<\mathrm{F}$ tabel, maka $\mathrm{H}_{0}$ diterima dan dapat disimpulkan bahwa tidak ada variabel independen yang mempengaruhi variabel dependennya.

\section{HASIL DAN PEMBAHASAN}

Analisis statistik deskriptif digunakan untuk memberikan sebuah gambaran atau deskripsi mengenai suatu data yang dapat dilihat dari nilai rata-rata (mean), nilai tertinggi (maximum), nilai terendah (minimum), standar deviasi dari masingmasing variabel, kurtosis dan skewness (standar kemiringan). Dalam penelitian ini terdiri dari variabel bebas yaitu good corporate governance, return on asset, dan dividen payout ratio, serta variabel terikat yaitu nilai perusahaan. Pengolahan analisis statistik dalam pengolahan ini menggunakan Eviews 8. Terdapat 98 sampel yang digunakan dalam pengamatan, sehingga menunjukan data dari hasil statistik deskriptif sebagai berikut:

Tabel 2. Statistik Deskriptif

\begin{tabular}{lcccc}
\hline & GCG & ROA & DPR & NP \\
\hline Mean & 0,862143 & 0,862143 & 0,862143 & 0,862143 \\
Median & 0.900000 & 0.070000 & 0.360000 & 1.940000 \\
Maximum & 1.000000 & 0.470000 & 1.490000 & 82.44000 \\
Minimum & 0.490000 & 0.010000 & 0.000000 & 0.240000 \\
Std. Dev. & 0.136806 & 0.079194 & 0.290520 & 13.00737 \\
Skewness & -0.980024 & 2.121584 & 1.258118 & 4.100414 \\
Kurtois & 3.225224 & 8.845443 & 4.831027 & 20.56566 \\
Jarque-Bera & 15.89443 & 213.0425 & 39.54343 & 1534.542 \\
Probability & 0.000354 & 213.0425 & 39.54343 & 1534.542 \\
Sum & 84.49000 & 9.050000 & 42.80000 & 593.3700 \\
Sum Sq. Dev. & 1.815450 & 0.608360 & 8.186955 & 16411.60 \\
Observations & 98 & 98 & 98 & 98 \\
\hline
\end{tabular}


Berdasarkan Tabel 2 dapat diketahui hasil uji statistik deskriptif bahwa terdapat 98 pengamatan (observations). Variabel independen terdiri dari good corporate governance (GCG), return on asset (ROA) dan dividen payout ratio (DPR), sedangkan variabel dependen terdiri dari nilai perusahaan.

Variabel GCG memiliki nilai berkisar antara 0,49 atau 49\% sampai 1,00 atau $100 \%$. Perusahaan dengan skor GCG terendah 0,49 pada PT Summarecon Agung Tbk dan tertinggi sebesar 1,00 terdapat pada 11 perusahaan diantaranya adalah pada PT Ace Hardware Indonesia Tbk, PT Unilever Indonesia Tbk, PT Indofood CBP Sukses Makmur Tbk. Hal ini menunjukan bahwa hanya sekitar 11 perusahaan yang mencapai skor $100 \%$ dalam menerapkan GCG. Adapun nilai ratarata penerapan GCG untuk seluruh sampel sebesar $86 \%(0,862143)$.

Variabel profitabilitas yang dihitung dengan ROA memiliki nilai berkisar antara 0,01 sampai 0,47 . Perusahaan yang memiliki nilai ROA terendah 0,01 yaitu PT Salim Ivomas Pratama Tbk. Sedangkan ROA tertinggi sebesar 0,47 yaitu PT Unilever Indonesia Tbk. Sementara itu nilai rata-rata ROA sebesar 9\% (0.09), hal ini dapat diintepretasikan jika perusahaan yang terdaftar di JII 70 pada tahun 20182019 mampu menghasilkan laba atas pengelolaan aset yang dimiliki sebesar 9\%.

Variabel kebijakan dividen yang diukur dengan rasio DPR memiliki nilai berkisar antara 0,00 sampai 1,49. Nilai DPR terendah sebesar 0.00 yaitu PT Sentul City Tbk sedangkan nilai tertinggi sebesar 1,49 pada PT Indo Tambangraya Megah Tbk. Sementara itu nilai rata-rata DPR sebesar 43\% (0.436735). Hal ini menunjukkan sekitar $43 \%$ perusahaan yang terdaftar di JII 70 pada tahun 20182019 membagikan laba yang dihasilkan dalam bentuk rasio pembayaran dividen.

Variabel nilai perusahaan yang diukur dengan Price to Book Value (PBV) memiliki nilai berkisar antara 0,24 hingga 82,44. Nilai PBV terendah sebesar 0,24 pada PT Global Mediacom Tbk, sedangkan nilai tertinggi sebesar 82,44 pada PT Unilever Indonesia Tbk. Sementara itu nilai rata-rata sebesar 6.054796 (nilai PBV diatas satu), hal ini menandakan bahwa setiap perusahaan yang terdaftar di JII 70 memiliki nilai yang bagus di mata para investor.

Berdasarkan model regresi data panel menggunakan Fixed Effect Model (FEM), maka diperoleh persamaan regresi data panel sebagai berikut, Nilai Perusahaan $=6.604326+4.309941+57.47688+2.387030$. Uji t digunakan untuk 
melihat seberapa besar pengaruh variabel independen secara parsial terhadap variabel independen. Pengujian secara parsial bertujuan untuk menguji pengaruh setiap variabel independen terhadap variabel independennya.

Good corporate governance merupakan seperangkat peraturan yang mengatur hubungan antara pemegang saham, pengelola perusahaan, pihak kreditur, pemerintah, karyawan serta para pemegang kepentingan internal dan eksternal lainnya yang berkaitan dengan hak dan kewajiban mereka. Tujuan dari penerapan corporate governance digunakan pengendali perusahaan dalam upaya memberikan nilai tambah bagi perusahaan untuk menarik para investor. Dengan adanya penerapan corporate governance pada setiap perusahaan akan meningkatkan kinerja perusahaan melalui terciptanya proses pengambilan keputusan yang lebih baik sehingga pencapaian efisiensi operasional perusahaan tercapai dan meningkatkan pelayanan kepada stakeholders (Ayuningrum \& Saputra, 2017: 24).

Temuan penelitian menunjukkan bahwa variabel good corporate governance memiliki nilai probabilitas sebesar 0.6723 lebih besar dari nilai $\alpha$ yaitu $0.05(0.6723>0.05)$ maka $\mathrm{H}_{0}$ diterima dan $\mathrm{H}_{\mathrm{a}}$ ditolak, sehingga dapat disimpulkan bahwa tidak ada pengaruh signifikan antara variabel good corporate governance terhadap nilai perusahaan. Hasil penelitian ini didukung dengan teori yang dikemukakan oleh Daniri yang mengatakan bahwa corporate governance atau tata kelola perusahaan dapat meningkatkan nilai saham perusahaan sekaligus dapat meningkatkan citra perusahaan dimata publik dalam jangka panjang (Daniri, 2005: 24). Namun untuk meningkatkan nilai perusahaan, penerapan good corporate governance harus diikuti dengan peningkatan kualitas penerapan good corporate governance dari masing-masing perusahaan tersebut (Muchtar, 2021: 233).

Hasil penelitian ini sesuai dengan penelitian yang dilakukan Rachman, Rahayu dan Topowijono (2015: 8) dalam penelitiannya mengatakan bahwa investor dalam menanamkan modalnya ke perusahaan tidak memperhatikan perusahaan tersebut sudah menerapkan good corporate governance atau belum. Begitu juga penelitian yang dilakukan oleh Susilo, Sulastri dan Isnurhadi (2018: 63) dengan teknik analisis Structural Equation Modelling (SEM) menujukkan good corporate governance tidak berpengaruh terhadap kinerja keuangan dan juga tidak berpengaruh terhadap nilai perusahaan. Hal ini juga didukung oleh hasil penelitian 
yang dilakukan oleh Muchtar (2021: 232) tata kelola perusahaan tidak berpengaruh terhadap nilai perusahaan.

Profitabilitas merupakan rasio yang digunakan untuk menilai kemampuan perusahaan dalam mencari keuntungan. Rasio ini juga memberikan ukuran tingkat efektivitas manajemen suatu perusahaan. Hal ini ditujukan oleh laba yang dihasilkan dari penjualan dan pendapatan investasi (Agustina \& Rahmiyati, 2019: 93). Return on Assets (ROA) adalah tingkat keuntungan bersih yang berhasil diperoleh perusahaan dalam menjalankan operasionalnya. Return on assets diukur dari laba bersih setelah pajak (earnings after tax) terhadap total aset yang mencerminkan kemampuan perusahaan dalam penggunaan investasi yang digunakan untuk operasi perusahaan dalam rangka menghasilkan profitabilitas (Samosir, 2017: 77).

Temuan penelitian ini menunjukan bahwa hasil estimasi nilai probabilitas ROA sebesar 0.0347 lebih kecil dari nilai signifikansi yaitu $0,05(0,0347<0,05)$. Hal ini menandakan bahwa $\mathrm{H}_{\mathrm{a}}$ diterima yang berarti ROA berpengaruh signifikan terhadap nilai perusahaan. Hasil dari penelitian ini sesuai dengan hipotesis $\mathrm{H}_{\mathrm{a}}$, dimana ROA berpengaruh signifikan terhadap nilai perusahaan. Tingginya laba yang diperoleh perusahaan maka akan semakin tinggi nilai ROA yang dihasilkan, sehingga semakin efisien penggunaan aset perusahaan dalam menghasilkan laba bersih yang lebih besar dan semakin baik nilai perusahaan dimata investor.

Hasil penelitian ini sesuai dengan teori yang dikemukakan oleh Musabbihan dan Purnawati (2018: 1.998) yang menyatakan bahwa ketika profitabilitas perusahaan meningkat, maka akan direspon positif oleh investor sehingga nilai perusahaan juga akan meningkat. Sebagian besar investor cenderung menilai perusahaan melalui laba yang dihasilkan oleh perusahaan, karena menganut profit oriented. Hal ini juga sesuai dengan konsep dari signaling theory yang mengatakan bahwa profitabilitas suatu perusahaan akan menjadi sinyal positif dari manajemen yang menggambarkan prospek perusahaan.

Kebijakan dividen merupakan keputusan yang diambil perusahaan mengenai apakah laba yang diperoleh perusahaan pada akhir tahun akan dibagi kepada pemegang saham dalam bentuk dividen atau akan ditahan untuk menambah modal guna pembiayaan investasi dimasa yang akan datang (Dominique, 2019). 
Kebijakan dividen dapat dilihat dari nilai Dividend Payout Ratio (DPR). Dalam penelitian ini diperoleh hasil DPR sebesar 0,6606 lebih besar dari nilai signifikansi yaitu $0,05(0,6606>0,05)$, hal ini menandakan bahwa $\mathrm{H}_{0}$ diterima dan dapat disimpulkan bahwa kebijakan deviden tidak berpengaruh signifikan terhadap nilai perusahaan.

Hasil penelitian ini sesuai dengan penelitian yang dilakukan oleh Hidayah dan Widyawati (2016: 18) yang menunjukkan kebijakan deviden tidak berpengaruh terhadap nilai perusahaan. Meningkatnya nilai deviden tidak selalu diikuti dengan meningkatnya nilai perusahaan. Begitu juga Pramesty dan Cahyono (2020: 1) memperoleh hasil penelitian jika kebijakan deviden tidak berpengaruh signifikan terhadap nilai perusahaan. Selain itu hasil penelitian ini sesuai dengan teori yang dikemukakan oleh Martha, Sogiroh, Magdalena, Susanti dan Syafitri (2018) yang menyatakan bahwa jika dividen menurun maka nilai perusahaan akan meningkat, karena akan menyebabkan menguatnya dana internal perusahaan karena laba ditahan perusahaan meningkat, sehingga kinerja perusahaan juga meningkat yang mengakibatkan naiknya nilai perusahaan. Pernyataan tersebut sesuai dengan data yang dikumpulkan oleh peneliti, dimana rata-rata DPR pada sampel penelitian sebesar 0,436735 atau sekitar $43 \%$ perusahaan yang membayarkan deviden hampir $100 \%$ dari laba yang dihasilkan oleh perusahaan. Oleh sebab itu tingginya DPR menyebabkan laba ditahan yang dimiliki perusahaan sedikit sehingga dana internal yang dimiliki pun sedikit. Hal ini menyebabkan kinerja perusahaan akan menurun dan berdampak terhadap menurunnya nilai perusahaan.

Pengaruh good corporate governance, profitabilitias, dan kebijakan deviden secara simultan terhadap nilai perusahaan dapat terlihat dari hasil Uji F. Temuan penelitian menunjukkan hasil nilai F-hitung sebesar 16,14402 sedangkan F-tabel dengan tingkat signifikansi $\alpha=0,05$ adalah sebesar 2,70. Hal ini berarti bahwa nilai F-hitung lebih besar dari F-tabel $(16,14402>2,70)$. Selain itu dihasilkan nilai probabilitas sebesar 0,000000 yang berarti lebih kecil dari tingkat signifikansi $\alpha$ sebesar 0.05 sehingga H0 ditolak dan Ha diterima. Maka dapat disimpulkan bahwa variabel good corporate governance, profitabilitas, dan kebijakan deviden secara simultan berpengaruh signifikan terhadap nilai perusahaan. 


\section{KESIMPULAN}

Berdasarkan hasil penelitian dan pembahasan dapat ditarik kesimpulan sebagai berikut:

1. Variabel good corporate governance (GCG) yang diukur dengan Penerapan Pedoman Tata Kelola Perusahaan Terbuka tidak berpengaruh signifikan terhadap nilai perusahaan.

2. Variabel profitabilitas yang diukur dengan Return on Asset (ROA) berpengaruh signifikan terhadap nilai perusahaan.

3. Variabel kebijakan dividen yang diukur dengan Dividend Payout Ratio (DPR) tidak berpengaruh signifikan terhadap nilai perusahaan.

4. Variabel good corporate governance, profitabilitas dan kebijakan deviden (GCG, ROA, DPR) secara simultan berpengaruh terhadap Nilai Perusahaan.

\section{PUSTAKA ACUAN}

Abdalloh, Irwan. (2018). Pasar Modal Syariah. Jakarta: PT Elex Media Komputindo

Agustina, R., \& Rahmiyati, N. (2019). Pengaruh Kinerja Keuangan Dan Kebijakan Dividen Terhadap Nilai Perusahaan Telekomunikasi Yang Terdaftar Di Bursa Efek Indonesia Periode 2011-2016. Jurnal Ekonomi Manajemen, 4 (1), 91107

Ayuningrum, N., \& Saputra, R. D. (2017). Pengaruh Penerapan Good Corporate Governance Terhadap Nilai Saham Perusahaan Dengan Profitabilitas Sebagai Variabel Intervening Pada Perbankan Syariah Yang Terdaftar di Bursa Efek Indonesia. Jurnal Akuntanika, 3 (2), 22-29

Basuki, A. T., \& Prawoto, N. (2016). Analisis Regresi Dalam Penelitian Ekonomi \& Bisnis: Dilengkapi Aplikasi SPSS \& EVIEWS. Depok: PT Rajagrafindo Persada

Brigham, E. F., \& Gapenski, I.C. (2011). Intermediate Financial Management, Fifth Edition. New York: The Dryden Press

Brigham, E. F., \& Houston, J.F. (2001). Manajemen Keuangan, Edisi Kedelapan. Jakarta: Erlangga

Daniri, M. A. (2005). Good Corporate Governance: Konsep Dan Penerapannya Dalam Konteks Indonesia. Cetakan I. Jakarta: PT Ray Indonesia

Dominique, J. (2019). Pengaruh Kebijakan Dividen, Likuiditas, Profitabilitas, Ukuran Perusahaan, Keputusan Pendanaan, dan Keputusan Investasi terhadap Nilai Perusahaan (Studi pada Perusahaan Manufaktur yang Terdaftar di Bursa Efek Indonesia Tahun 2015-2017). Thesis. Universitas Multimedia Nusantara

Fahmi, I. (2014). Analisis Laporan Keuangan. Bandung: Alfabeta

Fahmi, I. (2014). Studi Kelayakan Bisnis dan Keputusan Investasi. Jakarta: Mitra Wacana Media 
Ganar, Y. B. (2018). Pengaruh Kebijakan Dividen Terhadap Nilai Perusahaan Pada Perusahaan Yang Terdaftar Di Bursa Efek Indonesia Periode 2013-2017. Jurnal Sekuritas (Saham, Ekonomi, Keuangan dan Investasi), 2 (1), 32-44

Ghozali, I., \& Dwi, R. (2016). Analisis Multivariat dan Ekonometrika: Teori, Konsep dan Aplikasi dengan Eviews 8. Semarang: Universitas Diponegoro

Gitman, L. (2006). J. Principles of Manajerial Finance. International Edition, 10 th edition. Boston: Pearson Education

Hidayah, N., \& Widyawati, D. (2016). Pengaruh Profitabilitas, Leverage Dan Kebijakan Deviden Terhadap Nilai Perusahaan Food and Beverages. Jurnal Ilmu dan Riset Akuntansi, 5 (9), 1-19

Kurnianto, Wahyutama Aptria, Sudarwati dan Burhanudin. (2019). Mekanisme Good Corporate Governance terhadap Kinerja Perusahaan yang Terdaftar di Jakarta Islamic Index (JII) Tahun 2014-2016. Jurnal Manajemen dan Keuangan, 8 (1), 12-20

Kuncoro, M. (2013). Metode Riset Untuk Bisnis dan Ekonomi. Edisi 4. Jakarta: Erlangga

Lestari, (2019). Analisis Pengaruh Kinerja Keuangan Terhadap Nilai Perusahaan Dengan Corporate Social Responsibility (CSR) Sebagai Variabel Moderasi Tahun 2018 (Studi Kasus Pada Perusahaan ISSI). Thesis. Universitas Trisakti

Lukviarman, N. (2016). Corporate Governance Menuju Penguatan Konseptual Dan Implementasi Di Indonesia. Solo : PT Era Adicitra Media

Martha, L., Sogiroh, N.U., Magdalena, M., Susanti, F., \& Syafitri, Y. (2018). Profitabilitas dan Kebjiakan Dividen Terhadap Nilai Perusahaan. Jurnal Benefita, 3 ( 2), 227-238

Muchtar, E. H., Nuruddin, A., \& Siregar, S., (2019). Peningkatan Nilai Perusahaan Melalui Tata Kelola Perusahaan Dan Profitabilitas Pada Konstituen Indeks Saham Syariah Indonesia. Malia: Jurnal Ekonomi Islam, 10 (2), 181-199

Muchtar, E. H. (2021). Corporate Governance: Konsep Dan Implementasinya Pada Emiten Saham Syariah. Indramayu: Penerbit Adab

Munawir, S. (2007). Analisa Laporan Keuangan. Yogyakarta: Liberty

Musabbihan, N.A., \& Ni Ketut Purnawati, N.K. (2018). Pengaruh Profitabilitas Dan Kebijakan Dividen Terhadap Nilai Perusahaan Dengan Struktur Modal Sebagai Pemediasi. E-Jurnal Manajemen Unud, 7 (4), 1.979-2.009

Mustafa \& Junaid, A. (2018). Efek Moderating Kebijakan Deviden Dalam Pengaruh Keputusan Investasi Terhadap Nilai Perusahaan (Studi Empiris Pada Perusahaan Islamic Index Indonesia (JII) yang Terdaftar di Bursa Efek Indonesia). Yume: Journal of Management, 1 (3), 9-21

Nursito. (2019). Pengaruh Penerapan Good Corporate Governance, Struktur Modal Terhadap Nilai Perusahaan Dengan Kinerja Keuangan Sebagai Variabel Moderating (Studi Empiris Pada Perusahaan Sektor Barang Konsumsi di Bursa Efek Indonesia Tahun 2013-2017. Journal of Accounting and Finance, 4 (2), 832-848

Organization for Economic Co-operation and Development/O.E.C.D. (1999). OECD Principles of Corporate Governance. Paris: OECD

Otoritas Jasa Keuangan. (2015). Peraturan Otoritas Jasa Keuangan No.21/POJK.04/2015 tentang Penerapan Pedoman Tata Kelola Perusahaan Terbuka jo. Surat Edaran Otoritas Jasa Keuangan No.32/SEOJK.04/2015 
tentang Pedoman Tata Kelola Perusahaan Terbuka. Jakarta: Otoritas Jasa Keuangan

Otoritas Jasa Keuangan. (2019). Buku 8 Industri Jasa Keuangan Syariah. Seri Literasi Keuangan Perguruan Tinggi. Jakarta: Otoritas Jasa Keuangan

Pramesty, O., \& Cahyono, K.E. (2020). Pengaruh Profitabilitas, Leverage Dan Kebijakan Deviden Terhadap Nilai Perusahaan Food And Beverages Yang Terdaftar Di BEI. Jurnal Ilmu dan Riset Manajemen, 9 (4), 1-14

Primadhyta, S. (2017, September 10). OJK: Praktik GCG Perusahaan Indonesia Masih Tertinggal. Dipetik Maret 5, 2020, dari CNN Indonesia: https://cnnindonesia.com

Purnama, H. (2016). Pengaruh Profitabilitas, Kebijakan Hutang, Kebijakan Deviden, dan Keputusan Investasi Terhadap Nilai Perusahaan (Studi Kasus Perusahaan Manufaktur yang Go Publik di Bursa Efek Indonesia) Periode 2010-2014. Jurnal Akuntansi, 4(1), 11-21

Puspitaningtyas, Z. (2017). Efek Moderasi Kebijakan Dividen Dalam Pengaruh Profitabilitas Terhadap Nilai Perusahaan. Jurnal Akuntansi, Ekonomi dan Manajemen Bisnis. 5.(2), 173-180

Putra, I.P.M.J.S., \& Juniariani, N.M.R. (2017). Analisis Rasio Keuangan Terhadap Nilai Perusahaan Di Bursa Efek Indonesia”, Jurnal Riset Akuntansi, 7 (2), 143-150

Rachman, A. N., Rahayu, S. M., \& Topowijono. (2015). Pengaruh Good Corporate Governance (GCG) dan Financial Leverage Terhadap Kinerja Keuangan dan Nilai Perusahaan. Jurnal Administrasi Bisnis (JAB), 27 (1), 1-10

Samosir, H.E.S. (2017). Pengaruh Profitabilitas dan Kebijakan Utang terhadap Nilai Perusahaan yang terdaftar di Jakarta Islamic Index (JII). Journal of Business Studies, 2 (1), 75-83

Senjani, Y.P., \& Wibantoro, R.I. (2018). Information Content Hypotesis Pada Saham Terindeks JII. Jurnal Ilmu Akuntansi, 11 (2), 282-292

Setiawan, F., \& Riduwan, A. (2015). Pengaruh ROA, Ukuran Perusahaan Pada Nilai Perusahaan : DPR Sebagai Variabel Pemoderasi. Jurnal Ilmu \& Riset Akuntansi, 4 (8), 1-17

Siyoto, S., \& Sodik, M. A. (2015). Dasar Metodologi Penelitian. Yogyakarta: Literasi Media Publishing

Sugiyono. (2017). Metode Penelitian Kuantitatif, Kualitatif dan $R$ \& D. Bandung: Alfabeta

Susilo, A., Sulastri \& Isnurhadi. (2018). Good Corporate Governance, Risiko Bisnis dan Kinerja Keuangan Terhadap Nilai Perusahaan. Jurnal Analisis Bisnis Ekonomi, 16 (1), 63-72

Sutedi, A. (2012). Good Corporate Governance. Jakarta: Sinar Grafika

Wareza, M. (2019, Desember 6). Kronologi Harley Selundupan Berujung Pemecatan Dirut Garuda. Dipetik Maret 5, 2020, dari CNBC Indonesia: https://cnbcindonesia.com

Weston, J.F., \& Copeland, T. E. (2001). Manajemen Keuangan Jilid I, Edisi Ke-9. Jakarta: Binarupa Aksara

Widyanti, R. A. (2014). Pengaruh Profitabilitas, Dividend Payout Ratio, dan Corporate Social Responsibility terhadap Nilai Perusahaan Sektor Manufaktur”. Jurnal Ilmu Manajemen (JIM), 2 (3), 1.048-1.057 